ks. Robert Kantor

Ius Matrimoniale

$31(2020) \mathrm{nr} 2$

DOI:10.21697/im.2020.31.2.07

Wydział Teologiczny Sekcja w Tarnowie UPJPII

ORCID 0000-0002-8599-7705

\title{
"Ne bis in eadem" based on the judgement of the Tribunal of the Rota of the Apostolic Nunciature in Spain coram Carlos Morán Bustos of $15^{\text {th }}$ June 2007
}

Content: Introduction. 1. What is the Spanish Rota. 2. Course of the analysed case. 3. Legal issues connected with the judgement in question. 3.1. Conformity of sentences. 3.2. Double consideration of the same case. 3.3. Reply of the Supreme Tribunal of the Apostolic Signatura of $3^{\text {rd }}$ June 1989 (no. 20598/88 V. T) - successive consideration of the case. 4. Conclusion of the Tribunal of the Rota of the Apostolic Nunciature in Spain in the analysed case.

\section{Introduction}

During the national meeting of ecclesiastical judges in Gródek nad Dunajcem in 2011, the subject of "Nullity of a judgement - examples from the case law of the Spanish Rota"1 was presented. During this lecture, examples of jurisprudence of the Tribunal of the Rota of the Apostolic Nunciature in Spain were quoted. Among the generally presented judgements, there was the judgement of the Auditor of

\footnotetext{
1 Cf. R. Kantor, Nieważność wyroku - przykłady z orzecznictwa Roty Hiszpańskiej, in: T. Rozkrut (ed.) Zalety oraz wady kanonicznego procesu o stwierdzenie nieważności małżeństwa. Materiały z ogólnopolskiego spotkania pracowników sądownictwa kościelnego w Gródku nad Dunajcem w dniach 13-14 czerwca 2011 roku, Tarnów 2012, Biblos Publishing House, p. 37-58.
} 
the Spanish Rota (Dean of this Rota), Carlos Morán Bustos, of $15^{\text {th }}$ June 2007. It is so interesting that it is worthy of note. Therefore, it is the subject of this study. This article refers to the analysis of the judgement related to the issuance of two sentences in the same case by the same tribunal (ne bis in eadem). First, a brief history of the Tribunal of the Rota of the Apostolic Nunciature in Spain will be presented and then the judgement of the Spanish Rota c. Bustos of $15^{\text {th }}$ June 2007 will be analysed.

\section{What is the Spanish Rota}

In the Roman Catholic Church, the judicial power is part of the power of governance, which, according to can. 135 of the Code of Canon Law (CIC), is distinguished as legislative, executive and judicial. The judicial function is contained in judging, that is, in declaring and applying the law to individual situations of dispute. This power is attributed to the pope and the bishops, but it is exercised daily and practically in the Church in a substitutive manner by persons and structures permanently established for its exercise, namely the Apostolic Tribunals and the episcopal tribunals ${ }^{2}$.

The Tribunal of the Rota of the Apostolic Nunciature in Spain, also known as the Tribunal of the Rota in Madrid or more commonly known as the Spanish Rota, is essentially an appellate tribunal and was established by privilege of the Holy See in the $16^{\text {th }}$ century. When talking about the Spanish Rota, it is important to bear in mind its historical development. First, mention should be made of the Nuncio's Tribunal, which carried out its judicial tasks in accordance with the powers that the Nuncio had in Spain. With the Apostolic Constitution "Administrandae iustitiae zelus" of $26^{\text {th }}$

2 Cf. T. Rozkrut, Jan Paweł II do Roty Rzymskiej (1979-2003), Tarnów 2003, p. 11: cf. A. DzIĘGA, Władza sędziego kościelnego, in: T. Rozkrut, Urzędy sądowewładza i służba. Materiały z ogólnopolskiego spotkania pracowników sądownictwa kościelnego w Gródku nad Dunajcem w dniach 11-12 października 2004 roku, Tarnów 2005, p. 21-22. 
March $1771^{3}$, Pope Clement XIV established the Tribunal of the Rota of the Apostolic Nunciature with an organisation very similar to the Roman Rota. From then on, the Spanish Rota was called the Clement's Rota (after Pope Clement XIV). The main difference with respect to the former Nuncio's Tribunal is that the Clement's Rota is an ordinary tribunal. According to the aforementioned Constitution of 1771, the new tribunal is not institutionally dependent on the exercise of the Nuncio's judicial powers. On $21^{\text {st }}$ June 1932, Pope Pius XI abolished the Rota in Madrid. This fact did not mean that efforts to restore its activities were abandoned. Intensive actions in this direction began in 1946. The restoration of the Rota of the Apostolic Nunciature became a fact by virtue of the motu proprio of Pius XII "Apostolico Hispaniarum Nuntio" of $7^{\text {th }}$ April 1947.4 Article 1 of the Norms of Pius's Rota reads: "The Rota of the Apostolic Nunciature, established in Madrid, is a collegial, ordinary tribunal, essentially a tribunal of appeal against ecclesiastical judgements rendered on Spanish territory". In this legal state, the Tribunal of the Rota of the Apostolic Nunciature in Madrid survived until $2^{\text {nd }}$ October 1999, when Pope John Paul II promulgated new norms through the motu proprio "Nuntiaturae Apostolicae in Hispania"5. The current Spanish Rota (the Rota of John Paul II), established in Madrid, is defined as a collegial, ordinary tribunal, essentially a tribunal of appeal to hear ecclesiastical judgements rendered on Spanish territory. In this way, the Spanish Rota is constituted as a territorial tribunal, since it has competence in cases transferred from Spanish territory. It should be added that this is a territorial tribunal - a special one that is governed by its own particular law. Through the motu proprio Nuntiaturae apostolicae in Hispaniae of $2^{\text {nd }}$ October 1999, John Paul II indicated

3 Cf. Clemente XIV, Breve Administrandae iustitiae zelus, in: Novísima Recopilación de las Leyes de España, vol. 1, Madrid 1805, p. 251-253.

4 Cf. Pius XII, Motu proprio Apostolico hispaniarum nuntio, 7 aprilis 1947, in: AAS 39 (1947), p. 155-163.

5 IoAnnes Paulus II, Motu proprio Nuntiaturae apostolicae in Hispania, 2 octobris 1999, in: AAS 92 (2000), p. 5-17. 
new norms for the Spanish Rota. The changes introduced by the Norms of 1999 allow us to speak of a new Tribunal. The organic and procedural norms of the Tribunal introduce a series of important modifications to the legal order of the Tribunal. According to the agreement between the Holy See and the Spanish State of 1979, the Spanish Rota ceased to be supported by the State. This situation disrupted the normal functioning of the Rota. The new norms of John Paul II were mainly oriented to the welfare of the Spanish faithful, as can be deduced from the Preamble of the papal document: "necesse esse consemus in fidelium spiritualis bonum ut Normae a Rota Nuntiaturae Apostolicae in Hispania servandae, que inde a die VII mensie Aprilis Anno MCMXLVII vigent, ad praesentia accomodentur, commutationes quoque sociales quae interea evenerunt ob oculos habentes ac parter tempo rum necessitates immutatas" ${ }^{\text {. The quoted }}$ Norms were also intended to adapt the functioning of the Spanish Rota to the Code of Canon Law of 1983 and the Apostolic Constitution Pastor Bonus. In this way, the Norms of 1947 and the Ordo iudicialis of 1952 became obsolete ${ }^{7}$.

The literature on the Spanish Rota is essentially in Spanish ${ }^{8}$. A monograph ${ }^{9}$ has been published in Polish and commentaries

\footnotetext{
6 Normy 1999, Preambuła, n. 2, in: IoAnnes Paulus II, Motu proprio Nuntiaturae apostolicae in Hispania, 2 octobris 1999, in: AAS 92 (2000), p. 5.

7 Cf. R. Kantor, Rota Hiszpańska. Struktura i działalność Trybunału Roty Nuncjatury Apostolskiej w Hiszpanii, (historical and legal study), Tarnów 2013, p. 19-24. 8 Cf. M. Calvo Tojo, Aportación del Tribunal de la Rota de la Nunciatura a la Iglesia Española, in: F.R. AzNAR GIL (ed.), La administración de la justicia eclesiástica en España, Salamanca 2001, p. 111-179; M. De La Puente Brunke, La Rota Española, Pamplona 2001 (PhD thesis written under the supervision of Prof. R. Rodríguez Ocaña, defence: $28^{\text {th }}$ June 2001); P. CAntero, La Rota Española, Madrid 1946; C. García Martín, El Tribunal de la Rota de la Nunciatura Apostólica de España, Roma 1961; J. Mantecón SANCHo, La restauración del Tribunal de la Rota de la Nunciatura en 1947, Santander 2007.

9 Cf. R. Kantor, Rota Hiszpańska. Struktura i działalność Trybunału Roty Nuncjatury Apostolskiej w Hiszpanii, op. cit.
} 
on the judgements of the Spanish Rota ${ }^{10}$ appear with increasing frequency. The judgement presented below should be added to those commentaries.

\section{Course of the analysed case}

The parties, $\mathrm{M}$ (petitioner) and $\mathrm{K}$ (respondent), were married on $3^{\text {rd }}$ September 1965 in the town of $\mathrm{C}$ in the archdiocese of Barcelona. The woman brought an action for canonical separation which was granted on $20^{\text {th }}$ August 1973. On the other hand, on $14^{\text {th }}$ October 1977, M (the petitioner) filed a petitioner's complaint with the Ecclesiastical Tribunal of Barcelona on the following grounds: defect of discretion of judgement on both sides and force or grave fear from without on the part of the petitioner. The Metropolitan Court of Barcelona gave a negative judgement on $3^{\text {rd }}$ May 1983, that is, that the nullity of the marriage had not been proved on any of the specified grounds. The parties did not appeal.

10 Cf. Z. Podlecki, Dekret ostateczny trybunału Roty Hiszpańskiej c. Faide z dnia 18 X 1974 r. w sprawie o nieważność matżeństwa z tytułu impotencji. Kościelne Prawo Procesowe. Materiały i studia, Lublin 1999, p. 237-246; ID., Dekret ostateczny trybunału Roty Hiszpańskiej c. Faide z dnia 18 X 1978 r. w sprawie o nieważność małżeństwa $z$ tytułu niezdolności psychicznej matżonka do wyrażenia zgody matżeńskiej w sposób wolny i świadomy oraz niezdolności mał̇̇onki do wyrażenia zgody $z$ racji niezdolności do podjęcia podstawowych obowiązków małżeńskich. Kościelne Prawo Procesowe. Materiały i studia, Lublin 1999, p. 247-252; ID., Dekret ostateczny trybunału Roty Hiszpańskiej c. Faide z dnia 27 I 1981 r. w sprawie o nieważność matżeństwa z tytułu bojaźni szacunkowej ze strony małżonki (can. 1087 \$ 1 CIC 1917). Kościelne Prawo Procesowe. Materiały i studia, Lublin 1999, p. 253-262; T. BiaŁoBRZESKI, Niezdolność do podjęcia istotnych obowiązków małżeńskich (can. 1095, no. 3 CIC) w świetle dekretu Trybunału Roty Nuncjatury Apostolskiej w Hiszpanii c. Panizo Orallo z 3 lutego 2000 roku, Ius Matrimoniale 15 (2010), p. 181-197; ID., Bojaźń szacunkowa (can. 1103 CIC) w świetle wyroku Trybunału Roty Nuncjatury Apostolskiej w Hiszpanii c. Morán Bustos z 12 grudnia 2003 roku, Ius Matrimoniale 16 (2011), p. 229-241: ID., Problematyka wykluczenia nierozerwalności małżeństwa w wybranych wyrokach Trybunału Roty Nuncjatury Apostolskiej w Hiszpanii, in: R. SzTyCHMiler, J. KrzywKowska (ed.), Małżeństwo na całe życie?, Olsztyn 2011, p. 207-217. 
Again on 23 ${ }^{\text {rd }}$ February 2005, M (the petitioner) brought the petitioner's complaint before the same tribunal on the grounds of defect of discretion of judgement as to the accepted matrimonial rights and duties and mental incapacity to assume the essential obligations of marriage on both sides. On $26^{\text {th }}$ April 2005, the formula of the dispute was set out: 1 . fear from without on the part of the petitioner; 2 . defect of discretion of judgement on both sides; 3 . incapacity to assume the essential obligations of marriage on both sides. The Tribunal in Barcelona delivered its judgement on $20^{\text {th }}$ January 2006, in which it declared the marriage void for defect of discretion of judgement on both sides. (There was no proof of nullity on the grounds of mental incapacity to assume the essential obligations of marriage and no proof of nullity on the grounds of fear from without on the part of the petitioner). On the basis of can. $1682 \$ 1$ of the Code of Canon Law, decisions were taken on $23^{\text {rd }}$ January 2006 to send the file to the Tribunal of the Spanish Rota. Then, on $7^{\text {th }}$ April 2006, the composition of the tribunal was appointed, but no procedural steps were taken until the court fees were paid, which took place on $16^{\text {th }}$ May 2006.

\section{Legal issues connected with the judgement in question}

The following legal issues will be discussed below: conformity of sentences in canon law, double consideration of the same case, successive consideration of the same case.

\subsection{Conformity of sentences}

The Code of Canon Law of 1917, the Document Provida Mater Ecclesiae and the Code of Canon Law of 1983 situated the ideas of formal conformity of the sentence, understanding that it takes place in the case of identical grounds of nullity. Thus, can. 1641, $1^{\circ}$ reads: "a res iudicata occurs: if a second concordant sentence is rendered between the same parties over the same issue and on the same cause for petitioning". However, the jurisprudence of the Roman Rota, in many sentences, situated the ideas of the formal conformity of 
judgements not only on the exact conformity of the specific ground of nullity, but also on the motivation of this judgement ${ }^{11}$.

There are sentences ${ }^{12}$ in which non-conformity between two judgements was declared even though the ground of nullity was the same, arguing that the legal basis was different. It is possible to imagine a case in which deception concerning some quality of the other party (the wife) was accepted as the ground of nullity of the marriage and the man (the petitioner) claims that he was deceived about two qualities of the wife (the respondent), both of which seriously disturbed the partnership of conjugal life. If, therefore, the first judgement recognises deception by the first particular quality while denying deception as to the second quality, and the second judgement does the reverse, that is, recognises the second quality while denying the first one, then we are dealing with two formally non-conforming judgements, even though on the same ground ${ }^{13}$. Similarly, two sentences on the grounds of lack of form would not be formally conforming if, for example, in the first one the defect concerned the lack of delegation for the priest who assisted at the ceremony of marriage, and in the second one it turned out that the assisting priest was deprived of his office. In this case - according to the auditor of the Spanish Rota - one can speak of apparent conformity.

The above idea is presented in Article $291 \$ 1$ of the Dignitas Connubii (hereinafter: DC), where we clearly read: "Two sentences

11 Cf. R. Kantor, Nieważność wyroku - przykłady z orzecznictwa Roty Hiszpańskiej, in: T. Rozkrut (ed.), Zalety oraz wady kanonicznego procesu o stwierdzenie nieważności małżeństwa. Materiały z ogólnopolskiego spotkania pracowników sądownictwa kościelnego w Gródku nad Dunajcem w dniach 13-14 czerwca 2011 roku, op. cit., p. 53.

12 Cf. S.R.R.D., coram Pinto of $6^{\text {th }}$ May 1974, vol. 66, 1974, p. 339-348.

13 Cf. J. Llobell, Il concetto di «conformitas sententiarum» nell Istr. "Dignitas Connubii» e i suoi riflessi sulla dinamica del processo, in: H. FranCESCHI, J. LloBELL, M. A., ORTIz (ed.), La nulità del matrimonio: temi processuali e sostantivi in occasione della "Dignitas Connubii». Il corso di aggiornamento per operatori del diritto processo i tribunali ecclesiastici, Roma 13-18 de settembre 2005, Roma 2005, p. 210. 
or decisions are said to be formally conforming if they have been issued between the same parties, concerning the nullity of the same marriage, and on the basis of the same ground of nullity and the same reasoning of law and of fact (cf. can. 1641, no. 1)". This article not only defines the formal conformity of the judgement by the same ground of nullity, but also speaks of "the same reasoning of law and of fact". If these arguments are different, one cannot speak of formal conformity. Article 291 \& 2 DC also speaks about “equivalent" or "conforming” judgements and states: "Equivalent, i.e. conforming in substance, are deemed to be those decisions which, although indicating and specifying different grounds of nullity, are nevertheless based on the same facts and on the same evidence which caused the nullity of marriage". The article thus edited places particular emphasis on two aspects: "The same facts", "the same evidence". Thus, in order for the judgements to be conforming in substance, it must first be verified that they are based on the same legal facts that make the marriage in question void. Second, it must be verified that they are also based on the same evidence that is necessary to confirm the legal facts ${ }^{14}$.

The issue of equivalent i.e. substantial conformity is important in other aspects of the process. E.g. the issue of equivalent conformity between two or more complaints presented by the same parties; someone presents a petitioner's complaint on the grounds of a mistake as regards a quality where there is already a negative ruling, but

\footnotetext{
14 J. Llobell notices that: „Dos decisiones aequivalenter conformes deben presentar características homogéneas no sólo los facta martimonii irritntia, es decir, los hechos jurídicos o principales, sino también las probationes, es decir, los hechos secundarios, que son necesarios para probar aquellos otros principales. Por tanto, la única divergencia permitida entre las dos decisiones concierne pura y simplemente el nomen iuris: es decir, que los hechos jurídcos o principales, demonstrados sobre la base de las msmas pruebas sustanciales, hayan sido puestos en relación con capita nullitatis diversos en las dos sentencias, con tal que, obviamente, ambas decisones concluyan con el mismo dictamen acerca de la ceretza moral sobre la nulidad o no del matrimonio". J. Llobell, Valor jurídico de la «Dignitas Connubii», in: H. FranCESCHI, J. Llobell, M.A., ORTIz (ed.), La nulità del matrimonio: temi processuali e sostantivi in occasione della «Dignitas Connubii», op. cit., p. 64-65.
} 
presents a petitioner's complaint on the grounds of a mistake that refers to another quality. Logically, such a complaint would have to be accepted. Another case where there are two negative judgements on the grounds of exclusion of offspring and a complaint is brought on the basis of a future condition not to have offspring. Here we are dealing with two different grounds, but the legal basis is equivalent, hence according to the auditor of the Rota of the Apostolic Nunciature in Spain - a new complaint should not be accepted, as this would violate the principle of ne bis in eadem ${ }^{15}$.

\subsection{Double consideration of the same case}

While speaking about double consideration of the same case, we have in mind a situation in which the same case - with subjective and objective elements - is received, instructed and adjudicated twice, by the same or different tribunal. Auditor Carlos Moràn Bustos, in his judgement, calls such a situation one of the greatest perversions from a procedural point of view, since it touches on the principles of procedural economy, legal certainty and the possibility of issuing opposing judgements ${ }^{16}$.

According to Prof. Acebal ${ }^{17}$, a case may be subject to double consideration or trial in a simultaneous or successive (consecutive) manner. Consideration of a case in a simultaneous manner occurs

15 Cf. R. Kantor, Nieważność wyroku - przykłady z orzecznictwa Roty Hiszpańskiej, in: T. RozKrut (ed.), Zalety oraz wady kanonicznego procesu o stwierdzenie nieważności małżeństwa. Materiały z ogólnopolskiego spotkania pracowników sądownictwa kościelnego w Gródku nad Dunajcem w dniach 13-14 czerwca 2011 roku, op. cit., p. 53.

16 Cf. R. Kantor, Nieważność wyroku - przykłady z orzecznictwa Roty Hiszpańskiej, in: T. Rozkrut (ed.), Zalety oraz wady kanonicznego procesu o stwierdzenie nieważności małżeństwa. Materiały z ogólnopolskiego spotkania pracowników sądownictwa kościelnego w Gródku nad Dunajcem w dniach 13-14 czerwca 2011 roku, op. cit., p. 54.

17 Cf. J.L. Acebal Luján, El fuero competente. Textos y comentarios a declaraciones recientes del S.T. de la Signatura Apostolica, Revista Española de Derecho Canónico 47 (1990), p. 212. 
when two judges, equally competent, intend to hear the case simultaneously. The procedural law makes use of a number of different institutions to avoid such situations and to uphold the principle of ne bis in eadem.

The first of these is the institution of prevention ${ }^{18}$, which means that only the court that first legitimately cited the respondent has the right of adjudicating the case. This refers to the legitimacy of the citation, in accordance with Articles 126 and 129 DC, and not to the fact of respondent's appearance in court. It is worth quoting Article $9 \$ 2$ DC which reads: "Thus the incompetence of a judge is absolute by reason of grade if the same cause, after a definitive sentence has been issued, is heard again in the same instance, unless the sentence happens to have been declared null; it is absolute by reason of matter if a cause of nullity of marriage is heard by a tribunal which is able to judge only causes of another type".

The second institution is by reason of connection $^{19}$. The idea is that all cases relating to one marriage must be brought before one court and heard by this court. Therefore, it is necessary to ask every petitioner whether the case of nullity of this marriage has not been or is not already being heard by another court.

It is also worth recalling can. $1512,5^{\circ}$ which informs us that after the citation has been communicated in accordance with the provisions of law, or when the parties have appeared before the judge to pursue the case, the litigation begins to be pending; therefore, the principle while litigation is pending, nothing is to be altered immediately takes effect. By citing the respondent, a procedural relationship is created between the parties. The citation must be served in accordance with the law either by actual service of the citation or when the respondent

\footnotetext{
18 "By reason of prevention, if two or more tribunals are equally competent, the right of adjudicating the case belongs to the one which legitimately cited the respondent first”. Can. 1415 CIC.

19 "By reason of connection, interconnected cases must be adjudicated by one and the same tribunal in the same process unless a prescript of law prevents this". Can. 1414 CIC. See DC, art. 15.
} 
has spontaneously appeared before the court. The effects of such a citation are defined as follows: the litigation begins to be pending; therefore, the principle while litigation is pending, nothing is to be altered immediately takes effect e.g. the petitioner may not withdraw or amend the complaint without the consent of the respondent ${ }^{20}$.

If the institution of prevention and litis pendentia is not respected, the second trial, as well as the second judgement, will be invalid, because in both cases the principle that prohibits ruling twice on the same case in the same degree of judicial hierarchy will be violated ${ }^{21}$.

\subsection{Reply of the Supreme Tribunal of the Apostolic Signatura of $3^{\text {rd }}$ June 1989} (no. 20598/88 V. T) $)^{22}$ - successive consideration of the case.

The issue which is the subject of the reply of the Apostolic Signatura was presented by a judicial vicar in the form of an enquiry and was addressed to the Pontifical Commission for the Authentic Interpretation of the Code of Canon Law. On 29th November 1988, this Commission sent this enquiry to the Apostolic Signatura. The subject of the consultation is the competence of the court in cases of nullity of marriage when there is a negative judgement. Specifically, the issue was presented as follows: "sententia negativa circam nulittatem matrimonii ab uno tribunali in primo iurisdictionis gradu lata, potestne aliud, quod vi can. 1673 sese aeque competens censet ad causam pertractandam, eandem novo examini in prima instantia subicere?"23. The question, therefore, is whether, in the case of a negative judgement rendered in a tribunal of first instance, that

\footnotetext{
20 Cf. R. Kantor, Nieważność wyroku - przykłady z orzecznictwa Roty Hiszpańskiej, in: T. Rozkrut (ed.), Zalety oraz wady kanonicznego procesu o stwierdzenie nieważności małżeństwa. Materiały z ogólnopolskiego spotkania pracowników sądownictwa kościelnego w Gródku nad Dunajcem w dniach 13-14 czerwca 2011 roku, op. cit., p. 55.

21 Cf. M. Cabreros de Anta, Comentario al Código de Derecho Canónico, vol. 3, Madrid 1963, p. 232.

22 AAS 8 (1989), p. 988-990.

23 AAS 8 (1989), p. 988.
} 
judgement can be reconsidered in the first instance, by a tribunal that is competent under can. $1673^{24}$.

The Auditor of the Spanish Rota believes that this issue was not purely theoretical, but corresponded to a specific practice that violated the legal order. The Apostolic Signatura drew attention to the following issues:

- In number two, it reminds that it is the same case ("inter easdem partes et ex eadem causa petendi", can. $1641,1^{\circ}$ ) and although in this issue it is not analysed which tribunal would be competent according to can. 1673, the existing valid judgement situates us in the second instance (not in the first one).

- In number three, it is pointed out that if the judgement was valid in the first instance, the only recourse is to the tribunal of appeal according to canons 1438-1439; $1444 \$ 1,1^{\circ} ; 1632$. It is not possible to refer to the tribunal which delivered the judgement, nor to another tribunal of first instance ("partes nequeunt eandem litem iterum coram eodem vel coram alio tribunali primi iurisdictionis gradus introducere, etenim: ne bis in eadem").

- In number four, it is stressed that the appellate tribunal is competent to hear the case, not only when there is a positive judgement (can. 1682), but also in the case of a negative judgement (can. 1628-1640). It should be noted that in the case of non-existence of two concordant judgements (“ $\$ 1$. If a second concordant sentence has been rendered in a case concerning

\footnotetext{
24 "In cases concerning the nullity of marriage which are not reserved to the Apostolic See, the following are competent: 1 / the tribunal of the place in which the marriage was celebrated; $2 /$ the tribunal of the place in which the respondent has a domicile or quasi-domicile; $3 /$ the tribunal of the place in which the petitioner has a domicile, provided that both parties live in the territory of the same conference of bishops and the judicial vicar of the domicile of the respondent gives consent after he has heard the respondent; 4 / the tribunal of the place in which in fact most of the proofs must be collected, provided that consent is given by the judicial vicar of the domicile of the respondent, who is first to ask if the respondent has any exception to make".
} 
the status of persons, recourse can be made at any time to the appellate tribunal if new and grave proofs or arguments are brought forward within the peremptory time limit of thirty days from the proposed challenge. Within a month from when the new proofs and arguments are brought forward, however, the appellate tribunal must establish by decree whether a new presentation of the case must be admitted or not. $\$ 2$. Recourse to a higher tribunal in order to obtain a new presentation of the case does not suspend the execution of the sentence unless either the law provides otherwise or the appellate tribunal orders its suspension according to the norm of can. $1650 \$ 3$; can. 1644"), we do not speak of a recourse to the appellate tribunal, at least in the strict sense, although, according to the auditor of the Spanish Rota, we could use this terminology in the broad sense.

- In number five, the Apostolic Signatura stresses the absolute nature of the limits of functional competence, the absolute incompetence of a tribunal that does not respect these limits, and the consequent irremediable nullity of the judgement (canons 1440; 1561; 1620, $\left.1^{\circ} ; 1459 \$ 1 ; 1626 ; 1654 \$ 2\right)^{25}$.

In view of the above issues, the declaration of the Apostolic Signatura is as follows: "a) interum in eadem nullitatis matrimonii, postquam lata fuit sententia definitiva - etiamsi negativa - interum in eadem instantia pertractari nequit, nisi forte agatur de querele nullitatis; b) si idem vel aliud tribunal id nihilominus attentat, eius incompetentia absoluta vel ab iis quorum interest excipienta est vel ex officio a iudice declaranda, et nova sententia forte lata insanabiliter nulla habenda est, neque umquam exsecution mandari potest; c) videre de merito huiusmodi causae nullitatis matrimonii, sive in casu appellationis sive i casu novae eiusdem propositionis, ad solum

\footnotetext{
25 R. KANTOR, Nieważność wyroku - przykłady z orzecznictwa Roty Hiszpańskiej, in: T. Rozkrut (ed.), Zalety oraz wady kanonicznego procesu o stwierdzenie nieważności małżeństwa. Materiały z ogólnopolskiego spotkania pracowników sądownictwa kościelnego w Gródku nad Dunajcem w dniach 13-14 czerwca 2011 roku, op.cit., p. 55-57.
} 
tribunal appellationis pertinet illius fori quod eam in primo gradu definivit" ${ }^{26}$. Thus, the same cause of the nullity of marriage ruled by a judgement, even a negative one, cannot be heard again in the same instance (unless it is null and void and a complaint for its nullity is presented); if, nevertheless, a tribunal were to try such a case, it would be absolutely incompetent and the judgement rendered would be null and void and unenforceable.

Dignitas Connubii adopted this declaration of the Apostolic Signatura and has its expression in Article 289 where we read: "Causes of the nullity of marriage never become res iudicata (cf. can. 1643). However, a matrimonial cause which has been judged by one tribunal can never be judged again by the same or another tribunal of the same grade, without prejudice to Art. $9 \$ 2, \$ 3$. This provision applies only if it is a matter of the same cause, that is, concerning the same marriage and the same ground of nullity"27.

\section{Conclusion of the Tribunal of the Rota of the Apostolic Nunciature in Spain in the analysed case}

In the case brought before the Tribunal of the Rota of the Apostolic Nunciature in Spain, we are dealing with absolute incompetence on the part of the Tribunal which has heard the same case for the second time $^{28}$. The Tribunal in Barcelona should dismiss the petitioner's complaint on the ground of defect of discretion of judgement as to the accepted matrimonial rights and duties. It should do so at any stage of the case (can. 1461). The second sentence furthermore contains some wording that is difficult to understand: "the essential material in this ground is contained in the judgement of the first trial"; "The petitioner seeks to reconsider this ground for nullity of the petitioner's marriage".

\footnotetext{
26 AAS 8 (1989), p. 990.

27 DC, art. 289.

28 "A judge who becomes aware of being absolutely incompetent at any stage of the case must declare the incompetence", can. 1461.
} 
The irremediable nullity of this judgement is based on the principle of ne bis in eadem. A matrimonial cause that has already been tried by a court can never be tried a second time by the same court or another court of the same degree. The tribunal of first instance is absolutely incompetent to hear the case in second instance. Article $289 \$ 2$ DC is very clear: "However, a matrimonial cause which has been judged by one tribunal can never be judged again by the same or another tribunal of the same grade, without prejudice to Article $9 \$ 2$." Article $9 \$ 2$ notes: "Thus the incompetence of a judge is absolute by reason of grade if the same cause, after a definitive sentence has been issued, is heard again in the same instance, unless the sentence happens to have been declared null; it is absolute by reason of matter if a cause of nullity of marriage is heard by a tribunal which is able to judge only causes of another type".

The judges conclude that it remains for the petitioner to request the second instance for either a revision or a new proposal of grounds, as pointed out by the Supreme Tribunal of the Apostolic Signatura in its declaration of $3^{\text {rd }}$ June 1989. Ultimately, the Tribunal of the Spanish Rota has annulled the judgement of the Metropolitan Tribunal of Barcelona of $20^{\text {th }}$ January 2006. Signed by: Carlos Morán Bustos Auditor Judge, Judges: Francisco Ponce Gallén, Alejandro Arellano Cedillo and Notary Public: Eduardo López Pérez.

\section{Abstract}

In the Roman Catholic Church, the judicial power is part of the power of governance, which, according to can. 135 of the Code of Canon Law, is distinguished as legislative, executive and judicial. The judicial function is contained in judging, that is, in declaring and applying the law to individual situations of dispute. This power is attributed to the pope and the bishops, but it is exercised daily and practically in the Church in a substitutive manner by persons and structures permanently established for its exercise, namely the Apostolic Tribunals and the episcopal tribunals.

One of such tribunals is the Tribunal of the Rota of the Apostolic Nunciature in Spain, known as the Tribunal of the Rota in Madrid or more commonly known as the Spanish Rota. It is essentially an appellate tribunal and was established by privilege of the Holy See in the $16^{\text {th }}$ century. The title 
of this article is: "Ne bis in eadem based on the judgement of the Tribunal of the Rota of the Apostolic Nunciature in Spain coram Carlos Morán Bustos of $15^{\text {th }}$ June $2007^{\text {". }}$. The subject of the judgement is the question of double consideration of the same case.

\section{Ne bis in eadem na podstawie wyroku Trybunału Roty Nuncjatury Apostolskiej w Hiszpanii coram Carlos Morán Bustos z 15 czerwca 2007 r.}

\section{Streszczenie}

W Kościele rzymskokatolickim władza sądownicza stanowi część władzy rządzenia, która zgodnie z kan. 135 KPK dzieli się na władzę ustawodawczą, wykonawczą i sądowniczą. Funkcja sądownicza zawiera się w sądzeniu, czyli w deklarowaniu i aplikowaniu prawa do pojedynczych sytuacji spornych. Władza ta przypisana jest jako własna papieżowi oraz biskupom, natomiast codziennie i praktycznie jest ona wykonywana w Kościele na sposób zastępczy przez osoby i struktury ustanowione na sposób stały do jej sprawowania, czyli przez Trybunały Apostolskie oraz trybunały biskupie.

Jednym z takich trybunałów jest Trybunał Roty Nuncjatury Apostolskiej w Hiszpanii zwany Trybunałem Roty w Madrycie lub najczęściej nazywany po prostu Rotą Hiszpańską. Jest to trybunał zasadniczo apelacyjny i został utworzony na mocy przywileju Stolicy Apostolskiej w XVI w. Przedmiotem artykułu jest komentarz do wyroku, w którym kluczowe jest zagadnienie podwójnego rozpatrywania tej samej sprawy.

Słowa kluczowe: Rota Hiszpańska, wyrok, ne bis in eadem, zgodność orzeczeń, nieważność wyroku

Keywords: Spanish Rota, judgement, ne bis in eadem, conformity of judgements, nullity of judgement

\section{Nota o autorze}

Ks. Robert Kantor - doktor habilitowany nauk prawnych w zakresie prawa kanonicznego, wykładowca prawa kanonicznego i wyznaniowego w Sekcji Teologicznej w Tarnowie Uniwersytetu Papieskiego Jana Pawła II w Krakowie, sekretarz czasopisma „The Person and the Challenges”, kanclerz kurii diecezjalnej w Tarnowie. 